AUTHORS: Samuele Ceruti ${ }^{1}, \mathrm{MD}$, Marco Roncador ${ }^{2,3}, \mathrm{MD}$, Olivier Gié ${ }^{4}, \mathrm{MD}$, Giovanni Bona ${ }^{2}, \mathrm{MD}$, Martina Iattoni ${ }^{2}, \mathrm{MD}$, Maira Biggiogero ${ }^{5}$ PhD, Pier Andrea Maida ${ }^{6}$, MD, COVID-19 Clinical Management Team, Christian Garzoni' ${ }^{2 * *}, \mathrm{PD}$, Romano Mauri ${ }^{1 * *}, \mathrm{MD}$

\title{
TITLE: Reduced mortality and shortened ICU stay in SARS-COV-2 patients: a low PEEP strategy
}

${ }^{1}$ Clinica Luganese Moncucco, Department of Critical Care, Via Moncucco 10, 6900 Lugano, Switzerland

${ }^{2}$ Clinica Luganese Moncucco, Internal Medicine Service, Via Moncucco 10, 6900 Lugano, Switzerland

${ }^{3}$ University Hospital Zurich, Department of Medical Oncology and Hematology, Rämistrasse 100, 8091 Zürich, Switzerland

${ }^{4}$ Clinica Luganese Moncucco, Surgery Service, Via Moncucco 10, 6900 Lugano, Switzerland

${ }^{5}$ Clinica Luganese Moncucco, Clinical Research Unit, Via Moncucco 10, 6900 Lugano, Switzerland

${ }^{6}$ Clinica Luganese Moncucco, Geriatric Service, Via Moncucco 10, 6900 Lugano, Switzerland

*all authors made equal contributions

**these authors contributed equally

COVID-19 Clinical Management Team: Carola Biondi*2 ${ }^{2}$ MD, Sara Canovi*4 ${ }^{4}$ MD, Mattia Cavagna $*^{2}$, MD, Bruno Di Mari $*^{2}$, MD, Zsofia Horvath ${ }^{4}$, MD, Rosambra Leo $*^{6}$, MD, Giorgia Lo Presti*2, MD, Giorgia Luvini $^{* 2}$, MD, Dario Meloni*2 ${ }^{2}$, MD, Francesca Orlando $*^{2}$, MD, Sara Ravasi*5 ${ }^{5}$, MD, Roberta Sonzini ${ }^{4}$, MD, Giuseppe Tinessa ${ }^{1}$

Corrisponding authors: Samuele Ceruti, MD - Department of Critical Care - Clinica Luganese Moncucco, Via Moncucco, 10 - 6900, Lugano, Switzerland

Phone: 00410919608111 -

e-mail:samuele.ceruti@moncucco.ch 


\begin{abstract}
Background Intensive Care Unit (ICU) management of COVID-19 patients with severe hypoxemia is associated with high mortality. We implemented a 'care map', as a standardized multidisciplinary approach to improve patients monitoring using: uniform patient selection for ICU admission, a low-PEEP strategy and a pharmacologic strategic thromboembolism management.

Methods A standardized protocol for managing COVID-19 patients and ICU admissions was implemented through accurate Early Warning Score (EWS) monitoring and thromboembolism prophylaxis at hospital admission. Dyspnea, mental confusion or $\mathrm{SpO}_{2}$ less than $85 \%$ were criteria for ICU admission. Ventilation approach employed low PEEP values (about $10 \mathrm{cmH}_{2} \mathrm{O}$ in presence of lung compliance $>40 \mathrm{~mL} / \mathrm{cmH}_{2} \mathrm{O}$ ) and $\mathrm{FiO}_{2}$ as needed. In presence of lower lung compliance $\left(<40 \mathrm{~mL} / \mathrm{cmH}_{2} \mathrm{O}\right)$ PEEP value was increased to about 14 $\mathrm{cmH}_{2} \mathrm{O}$.
\end{abstract}

Findings From March $16^{\text {th }}$ to April $12^{\text {nd }} 2020,41$ COVID-19 patients were admitted to our ICU from a total of 310 patients. $83 \%$ (34) of them needed mechanical ventilation. The ventilation approach chosen employed low PEEP value based on BMI (PEEP $11 \pm 3.8(10-12) \mathrm{cmH}_{2} \mathrm{O}$ if BMI $<30 \mathrm{Kg} / \mathrm{m}^{2}$; PEEP $15 \pm 3.26(12-18) \mathrm{cmH}_{2} \mathrm{O}$ if BMI $>30 \mathrm{Kg} / \mathrm{m}^{2}$ ). To date, ten patients $(24 \%)$ died, four $(9.7 \%)$ received mechanical ventilation, two were transferred to another hospital and $25(60.9 \%)$ were discharged from ICU after a median of nine days.

Interpretation A multimodal approach for COVID-19 patients is mandatory. The knowledge of this multi-organ disease is growing rapidly, requiring improvements in the standard of care. Our approach implements an accurate pre-ICU monitoring and strict selection for ICU admission, and allows to reduce mechanical ventilation, ICU stay and mortality.

Funding No funding has been required. 


\section{BACKGROUND}

Severe acute respiratory syndrome coronavirus 2 (SARS-CoV-2) is the cause of COVID-19, a pandemic that has affected more than 3,000,000 individuals and caused nearly 200,000 deaths since initial detection of the virus up to the end of April $2020^{1}$.

Epidemiologic data from China and Italy underline the severity of the syndrome, with a critical load for intensive care units (ICU) and a high mortality ${ }^{2,3}$. In this phase of the pandemic, detailed reports describing management for COVID-19 patients admitted to the ICU are relevant ${ }^{4}$ for a better clinical characterization and for guiding decision making in the severe hypoxemia affecting these subjects ${ }^{5}$. In particular, newer pathophysiological understanding of the disease, as reported by Cronin ${ }^{6}$, Nieman ${ }^{7}$, Gattinoni ${ }^{8}$ and Bendjelid ${ }^{9}$, are keys for a better clinical evaluation and management.

On the basis of this newer concepts of COVID-19, we structured a 'care map' based on three relevant aspects: standardized criteria selection for ICU admission, a strategic antithrombotic therapy and low PEEP strategy.

The aim of our report is to describe the achievement obtained, in terms of survival, ICU length-of-stay and duration of mechanical ventilation (MV), by a multidisciplinary intervention which required a strong collaboration between ICU and other Departments, comparing them with current data ${ }^{2,3}$. We further describe the demographic characteristics, coexisting conditions, critical care management and outcomes among patients admitted to Clinica Luganese Moncucco (CLM) ICU during the first four weeks of the outbreak in Canton Ticino area.

\section{METHODS}

\section{Study population and data}

A retrospective analysis was conducted on all consecutive patients with acute respiratory distress for COVID-19 pneumonia admitted to ICU from March $16^{\text {th }}$ to April $12^{\text {nd }}, 2020$. All patients' relevant data like demographics, severity score (NEMS - nine equivalents of nursing manpower use score -, SAPS - simplified acute physiology score -), clinical information and laboratory/radiological results were obtained during patient's hospitalization from electronic health records. Standard biological workup included complete blood count, CRP, ferritin, ASAT, ALAT, ionogram, creatinine, urea, D-dimer, Prothrombin Time (PT), activated Partial Thromboplastin Time (aPTT), fibrinogen, blood gas analysis, $\mathrm{SvO}_{2}$, pro-BNP, blood and urines cultures, urine research for Legionella antigen. A specific workup included a pulmonary ultrasound, a chest x-ray, transthoracic and transesophageal 
echocardiography (to establish the global cardiac function before any pronation). A thoracic CT-scan was considered available if it has been performed during the stay in the Internal Medicine Department during the last 24 hours before the admission in the ICU.

\section{Care Map description}

Indication for ICU admission and oro-tracheal intubation (OTI) was routinely established by the intensive care specialist or senior anesthesiologist on duty, according to the 'care map' based on standardized criteria selection, low PEEP strategy and pharmacologic antithrombotic management.

\section{Criteria selection for ICU admission}

Requests of counseling for ICU admission came from the Department of Internal Medicine and from the Emergency Department (ED). With the aim of quickly identifying the worsening of clinical conditions ${ }^{11,12}$, all consultations were recorded by reporting patient's symptoms, $\mathrm{SpO}_{2}$, blood gas analysis values (if available) and clinical decision for admission or not to the ICU. Patients presenting partial respiratory failure combining peripheral saturation $\left(\mathrm{SpO}_{2}\right)$ lower than $85 \%$ and dyspnea (or mental confusion), or patients with dyspnea (or mental confusion) alone, were eligible to be admitted in ICU. Exclusion criteria were the will of the patient not to be intubated, cardiocirculatory arrest following hypoxia, metastatic oncological disease, end-stage neurodegenerative disease, severe and irreversible chronic disease (heart failure NYHA IV, COPD GOLD D, liver cirrhosis Child-Pugh $>8$, severe dementia) ${ }^{10}$. With the aim to avoid a misleading interpretation in ICU mortality, we decided to perform an extra evaluation on patients excluded from ICU, to ensure about their survival status.

Ventilation settings - low PEEP strategy -

After endotracheal intubation, we initially provided low PEEP-value strategy based on BMI (PEEP $10 \mathrm{cmH}_{2} \mathrm{O}$ if BMI $<30 \mathrm{Kg} / \mathrm{m}^{2}$, PEEP $12 \mathrm{cmH}_{2} \mathrm{O}$ if BMI 30-50 Kg/m², PEEP $15 \mathrm{cmH}_{2} \mathrm{O}$ if BMI > $50 \mathrm{Kg} / \mathrm{m}^{2}$ ), subsequently adjusted in case of hypoxia $\left(\mathrm{PaO}_{2}<60 \mathrm{mmHg} / 8 \mathrm{kPa}\right)$ according to ARDSnet PEEP table ${ }^{13,14}$; in addition, we used protective ventilation strategy (TV 6-8 ml/Kg, $\left.\mathrm{P}_{\text {plat }}<30 \mathrm{cmH}_{2} \mathrm{O}\right)$ with permissive hypercapnia $(\mathrm{pH}>7.20)$ according to standard care ${ }^{15}$ and immediate pronation. A deep sedation was maintained during first 36 hours using Midazolam (and eventually Ketamine), adding a paralyzing agent (Rocuronium) during first 24 hours and 
medRxiv preprint doi: https://doi.org/10.1101/2020.05.03.20089318; this version posted May 8, 2020. The copyright holder for this preprint

(which was not certified by peer review) is the author/funder, who has granted medRxiv a license to display the preprint in perpetuity.

It is made available under a CC-BY-NC-ND 4.0 International license .

subsequently just in case of patient-ventilator asynchrony. Drugs dosages have adapted to pursue a Richmond Agitation and Sedation Scale (RASS) of -4 and a Train-Of-Four (TOF) around 1/4.

\section{Pharmacologic antithrombotic management}

Given the high risk of Deep Venous Thrombosis (DVT) and Pulmonary Embolism (PE) ${ }^{15}$, as patients were admitted to ICU we started with a 'liberal' prophylactic anticoagulation (Enoxaparine $60 \mathrm{mg}$ bid SC if weight > $80 \mathrm{Kg}$, Enoxaparine $40 \mathrm{mg}$ bid SC if weight $<80 \mathrm{Kg}$, Unfractioned Heparin in case of acute kidney injury AKI) associated with ultrasound Color-Doppler lower limbs daily monitoring. In case of plasmatic D-dimer level greater than $1^{\prime} 500 \mathrm{ng} / \mathrm{ml}$ or documented thrombosis, anticoagulation treatment was switched to a therapeutic dose (Enoxaparine $1 \mathrm{mg} / \mathrm{Kg}$ bid SC - Unfractioned Heparin in case of AKI at $14 \mathrm{UI} / \mathrm{Kg} / \mathrm{day}$ in perfusion, adapted according to anti-Xa values), according to our 'care map' concerning the antithrombotic management.

\section{Patients Clinical Evolution}

Intensive supportive care was managed according to the evolution of the inflammatory parameters (CRP, CK, LDH and ferritin) and the stability of the P/F-ratio after each supination during the following days. In case of a favorable evolution, sedation was reduced to RASS -3/-2 switching on Propofol. By improvement of blood oxygen levels, we proceeded to reduce $\mathrm{FiO}_{2}$ up to $35-40 \% \mathrm{FiO}_{2}$ values without reducing PEEP. Once all the clinical and biological inflammatory parameters were constantly reduced for almost three consecutive days, patients were gently weaned from PEEP by keeping a $\mathrm{PaO}_{2}>60 \mathrm{mmHg}(8 \mathrm{kPa})$. The choice of removing the endotracheal tube was made by the doctor in charge according to usual standard of care.

Deep vein thrombosis, PE, Ventilator-Associated-Pneumonia (VAP) and Acute Kidney Injury (AKI) have been the main complications arose in patients admitted to ICU: DVTs and PEs were defined as suspected with an increase in serum D-dimer values over $1,500 \mathrm{ng} / \mathrm{ml}$, while they were considered as confirmed by ultrasound or CT-scan positive finding, defined according to current clinical standards. VAPs were identified according to usual standard care ${ }^{16}$ with an increase in secretions, in their quality and quantity, requiring an increase in the $\mathrm{FiO}_{2}$ administration ${ }^{17}$. Each case of AKI RIFLE $\mathrm{F}$ requesting CVVHDF has also been reported. All complications, administered drugs and adverse events occurring during the stay in intensive care, were registered and reported in the electronic medical record. 


\section{Statistical analysis and comparison with current literature}

Descriptive statistics were used to summarize the clinical data collected. No statistical sample size calculation was performed. We present continuous measurements as mean (min-max, SD) otherwise as median (IQR) if they are normally distributed. Categorical variables were reported as counts and percentages. Test statistics and survival analysis were performed with R v.3.6.1 and the Kaplan-Meier estimator from CRAN "surv" package. Data was subsequently compared with a similar in number and follow-up cohort published by Bhatraju et a $1^{18}$ complete patient data was retrieved from the supplementary appendix.

\section{Ethics Committee permissions}

This study has been notified to the Ethics Committees of Canton Ticino. According to the local Federal rules, it has been approved as a clinical data collection case series.

\section{Role of the funding source}

No funding has been required. The corresponding author confirms that he had full access to all the data in the study and he had final responsibility for the decision to submit for publication.

\section{RESULTS}

\section{Pre-ICU patients' evaluation}

310 patients with COVID-19 symptoms presented to our Clinic. According to exclusion criteria, 54 of them were not admitted to the ICU as they had a "do not resuscitate" order (DNR) in place before hospital admission (Figure 1); on April $12^{\text {th }}, 14$ of DNR patients (25\%) died. Globally, 41 critically ill patients with laboratoryconfirmed SARS-CoV-2 infection were admitted to the ICU (Figure 1); 10 patients (24\%) has been admitted directly from the ED, 5 (12\%) from others hospitals and 26 (64\%) from internal consultation (Figure 1) Demographic and clinical characteristics of patients were shown in Table 1. Patients had a mean age of $64 \pm 16.5$ years; most of them were men, often burdened by one or more chronic medical conditions (Table 1). At ICU admission, most patients showed hemodynamic stability. A chest CT-scan was obtained in 23 (56\%) patients; all of them showed bilateral ground glass opacities and four of them showed consolidations in addition (Table 1).

\section{Mechanical ventilation}


At admission $\mathrm{PaO}_{2}: \mathrm{FiO}_{2}$ ratios had a median of $87(54-133)$; with a median $\mathrm{FiO}_{2}$ of $72 \%(60 \%-100 \%)$ at the

ICU admission. Thirty-two (78\%) patients received invasive MV, the others were treated with High-Flow Nasal Cannula (Table 2).

Globally, mean PEEP for patients with $\mathrm{BMI}<30 \mathrm{Kg} / \mathrm{m}^{2}$ was $11 \mathrm{cmH}_{2} \mathrm{O}(10-12$, SD 3.80), while mean PEEP for patients with $\mathrm{BMI}>30 \mathrm{Kg} / \mathrm{m}^{2}$ was $15 \mathrm{cmH}_{2} \mathrm{O}\left(12-18\right.$, SD 3.26). After the onset of $\mathrm{MV}$, the median $\mathrm{FiO}_{2}$ improved around 70\% (60\% - 85\%), with first $\mathrm{PaO}_{2}: \mathrm{FiO}_{2}$ ratio with a median of 147 (101 - 233) (Table 2).

Thirty-one $(75.6 \%)$ patients were placed in a prone position (with an average number of pronations of four). In these patients, $\mathrm{PaO}_{2}: \mathrm{FiO}_{2}$ ratio progressively improved during next days, with a median value of $100(67 \cdot 5-$ 153) during the first day, $142 \cdot 5(97 \cdot 6-232 \cdot 8)$ during the second day and $167(113-230)$ during the third day (Table 3).

\section{Pharmacologic antithrombotic management}

No patient presented any contraindication to be treated with parenteral anticoagulation; 15 (36\%) patients were simply treated through prophylaxis, while $26(63 \%)$ patients were managed by full therapeutic anticoagulation (12 - 46\% - with Unfractioned Heparin, 14 - 54\% - with LMWH). No patient presented any bleeding complication, nor clinical sign requiring anticoagulation reduction or removal.

\section{ICU patient cohort and survival}

The median length of ICU stay was nine days $(4-12 \cdot 5)$; the median duration of MV was seven days $(3-10)$ (Table 3). On $12^{\text {th }}$ April, of the 41 patients, ten (24.3\%) has died, four (9.7\%) are still in the ICU receiving MV (two endotracheal tube, two tracheostomy), two patients were transferred to another hospital and 25 (60.9\%) have been discharged from the ICU (Figure 2) in good medical condition with no additional death in the following 10 days. At 7 day from ICU discharge, 39 patients (95\%) presented a Karnofsky performance status of more than 80 . No patients have been reintubated within or after 72 hours.

\section{Patients excluded from ICU}

The Intensivist Consultant performed clinical counseling of 48 patients admitted to the Internal Medicine Department, ED or from other hospital. The mean age was $65 \pm 25$ years $(38-82)$, presenting $\mathrm{SpO}_{2}$ median of $90 \%$ (88 - 94), $\mathrm{PaO}_{2}$ median of $63.2 \mathrm{mmHg}(51 \cdot 35-76 \cdot 55)$, a $\mathrm{pCO}_{2}$ median of $35 \cdot 2 \mathrm{mmHg}(31 \cdot 9-39 \cdot 1)$ and a median value of $\mathrm{Hb}$ of $13.9 \mathrm{~g} / \mathrm{L}(12 \cdot 3-15 \cdot 4)$. Twenty-six of these patients moved to our ICU and five of them 
had already been intubated in other hospitals. Intriguingly, the remaining 22 patients consulted but not admitted improved their conditions from an initial median value of $\mathrm{SpO}_{2}$ of $87 \%$ (84-91\%) without being highly symptomatic nor requesting admission in ICU, even for extremely low $\mathrm{SpO}_{2}$ values, but with no symptoms of fatigue such as dyspnea (Figure 1).

\section{Comparison with a published similar cohort}

We compared our 41 patients with a cohort of 24 patients published by Bhatraju et al. ${ }^{18}$. Mean age of admission was comparable between the two studies (median $63 \pm 12$ vs $64 \pm 18$ yrs), with patients admitted in Lugano having a slightly lower BMI value $(29 \cdot 3 \pm 4.94$ vs $33 \cdot 2 \pm 7 \cdot 2$, p-val 0.007$)$. No significant difference was found in the hematological status of the two cohorts (WBC, Lymphocytes and Platelets) and comparable level of lactate, maximal CRP level during recovery and liver transaminases (Table 1). Median values of the lower P/F ratio were lower in our cohort at day $1(100(65-162)$ vs $142(94-177))$, but increased to $142 \cdot 5(95 \cdot 6-236 \cdot 25)$ and $167(110 \cdot 5-231)$ in day two and day three of MV, resulting comparable or higher with the ones reported by Bhatraju et al ${ }^{18}$.

Overall survival rate during and after ICU admission was longer in our cohort compared to what previously published with a median of 11 days (1-22) versus nine days (1-20) (p-value = 0-028. Figure 3$)$. Length of ICU stay was comparable in both sets (nine days $(4-12.5)$ vs nine (4-14) days) but characterized by a lower mortality $(10,24 \cdot 3 \%)$ in our center compared to the $50 \%$ mortality reported in Bhatraju et al. ${ }^{18}$. Median numbers of days of MV was shorter in our cohort (6.5 days (3 - 10)) than what reported in Seattle (8 days (2-20))

\section{DISCUSSION}

Acute respiratory distress induced by SARS-CoV-2 is a critical clinical condition associated with the COVID-19 pandemic ${ }^{19,20}$. It requires adequate preparation in terms of hospital structure, triage systems and clinical training ${ }^{21}$ in order to be correctly addressed and minimize the burden for the patients and the ICU capacity. As COVID-19 is a multisystemic disease, a multidisciplinary approach is mandatory ${ }^{4}$.

To optimize management of tachypnea without dyspnea, also with $\mathrm{SpO}_{2}$ lower than normal, surveillance tools such as routine and regular Early Warning Score (EWS) measurement (every 4 hours if stable, reduced hourly if $\left.\mathrm{SpO}_{2}<92 \%\right)^{11,21}$ were implemented for intermediate care patients. Patients with COVID-19 interstitial pneumonia present tachypnea correlating with the desaturation degree, without dyspnea or severe neurological 
symptoms or any organ damage. High pulmonary compliance is probably the responsible for the absence of dyspnea ${ }^{22}$; we waited until the onset of dyspnea or to a value of $85 \%$ of $\mathrm{SpO}_{2}$ before admitting any of the patients to the ICU; in such a way, an overload of the ICU was avoided. None of the 48 patients who after a specialist consultation were not admitted to ICU but only placed under clinical surveillance, died in a follow-up from seven up to 21 days. Most of these patients improved their clinical status without being dyspnoeic and some of them have already been discharged from the hospital.

Patients showing a worsening degree of dyspnea transferred to the ICU received "low PEEP ventilatory strategy", on the contrary to what has been reported in the literature ${ }^{20}$. After intubation we found lungs easy to ventilate, with a higher compliance (on average above $50 \mathrm{~mL} / \mathrm{cmH}_{2} \mathrm{O}$ ) compared to the "classic ARDS" ${ }^{22}$. Even if the "classic" criteria for defining the ARDS were confirmed ${ }^{23}$, there were aspects as the absence of a reduced lung compliance, a "baby-lung" and a consequent tendency to hypercapnia, which induced us to evaluate a more specific treatment, at least in the initial phase.

In according to ARDSnet PEEP table ${ }^{13,14}$, we preferred to ventilate patients with PEEP tailored to patients' own BMI, carefully following lungs physiology ${ }^{23,24}$. This approach would agree with Gattinoni et al ${ }^{22}$ and Bendjelid et al ${ }^{9}$, which suggested two different ICU patient populations in COVID-19 pneumonia. The first one presents a high lung compliance and a probable alveolitis, with a shunt effect due to loss of local hypoxic vasoconstriction; this population represents the great majority of our patients. The second one presents a low lung compliance and a picture of baby-lung compatible with "classic ARDS" (only two patients in our set).

The "low PEEP ventilatory strategy" we applied allowed us to decrease quickly sedation depth once the inflammation level was reduced. This strategy led to less complications (like ICU paralysis, delayed awakening, agitation, etc... ${ }^{18}$ and an easier and faster extubation without resorting to large-scale tracheotomy.

During daily screening of the lower limb ultrasound, COVID-19 ICU patients showed a high prevalence rate of DVTs and PEs, even under preventive anticoagulation. In addition, many patients had a marked increase in Ddimers level, partly linked to the finding of DVT and PE in other sites of the body, partly secondary to PE phenomena also on the pulmonary venous side. In this context, it appears reasonable to protect the patient through a pro-active anticoagulant approach than the normal routine. Furthermore, the fact that patients did not encounter any major bleeding phenomenon, supports the idea that in these patients a more aggressive 
anticoagulation may counterbalance a phenomenon of prothrombotic diathesis, even if the complete mechanism is still unclear.

We observed an increased survival compared to other groups (Figure 2 and 3) 2,18,24,25. A possible explanation could be that the relative low-pressure ventilation avoids transforming an initial alveolitis into an ARDSiatrogenic framework, in which the local ongoing inflammation is rather damaged than helped by high PEEP (generating a Ventilation-Induced-Lung Injury - VILI) in a context that is the "not-classic" ARDS. We observed a very few cases of "classic" ARDS and, in particular, the absence of ARDS cases at the time of admission to the ICU. Mortality in ICU is reported to be as high as $42-62 \%{ }^{2,24}$, while in our dataset is $24.3 \%$. Median days of MV reported by Bhatraju et al. (8 (2-20)) is longer $(6 \cdot 5(3-10))$ than what experienced in our clinical setting. In all, this suggests that a less traumatic approach to ventilation by low PEEP and avoiding unnecessary MV by delaying ICU admission can be of help in managing COVID-19 patients and in improving survival.

Our study was burdened by several limitations. First, it was a monocentric observational retrospective study, with a relatively small series of patients. Second, our comparison with current literature is performed on different patient populations, even if cohorts could be considered similar in terms of disease severity and biochemical investigations. This notwithstanding, early data are very encouraging and needs a validation in bigger prospective studies.

In conclusion, the implementation of a multimodal "holistic" approach for COVID-19 patients is highly recommended. We implemented EWS monitoring for intermediate care patients, in order to perform a strict selection of ICU admission and employ MV as little as necessary. MV ventilation was adapted to the real patient needs - i.e. PEEP tailored to patient's BMI - in order to reduce alveolar traumatism. Anticoagulation screening and therapy has been regulated in order to prevent any sign of thrombosis or thromboembolism. This multimodal program allowed us to reduce the number of ICU admissions, the number of ventilation days and mortality, and could be the base for a further specific patients' management in this specific contest.

\section{Declaration of interests}

All authors disclose any financial and personal relationships with other people or organizations. 
medRxiv preprint doi: https://doi.org/10.1101/2020.05.03.20089318; this version posted May 8, 2020. The copyright holder for this preprint (which was not certified by peer review) is the author/funder, who has granted medRxiv a license to display the preprint in perpetuity.

It is made available under a CC-BY-NC-ND 4.0 International license .

\section{Author Contributions}

S.C., M.R., O.G., M.B. designed the study, performed statistical analysis, and wrote the manuscript; G.B., M.I,

PA.M., C.B., S.C., M.C., B.D.M., Z.H., R.L., G.L.P., G.L., D.M., F.O., S.R., S.R., G.T. collected clinical data;

C.G., R.M. contributed to study design and interpretation of the data. 
medRxiv preprint doi: https://doi.org/10.1101/2020.05.03.20089318; this version posted May 8, 2020. The copyright holder for this preprint

(which was not certified by peer review) is the author/funder, who has granted medRxiv a license to display the preprint in perpetuity.

It is made available under a CC-BY-NC-ND 4.0 International license .

\section{REFERENCES}

1. Center for Systems Science and Engineering. Coronavirus COVID-19 global cases. 2019 (https://gisanddata.maps.arcgis.com/apps/opsdashboard/index/html\#/bda7594740fd40299423467b48e9ecf6).

2. Yang $\mathrm{X}, \mathrm{Yu} \mathrm{Y}, \mathrm{Xu} \mathrm{J}$ et al. Clinical course and outcomes of critically ill patients with SARS-CoV-2 pneumonia in Wuhan, China: a single-centered, retrospective, observational study. Lancet Respir Med 2020 Feb 24 - doi: $10.1016 / \mathrm{S} 2213-2600(20) 30079-5$

3. Grasselli G, Pesenti A, Cecconi M. Critical care utilization for the COVID-19 outbreak in Lombardy, Italy: early experience and forecast during an emergency response. JAMA 2020 March 13 - doi: 10.1001/jama.2020.4031

4. Xie J, Tong Z, Guan X, Du B, Qiu H, Slutsky AS. Critical care crisis and some recommendations during the COVID-19 epidemic in China. Intensive Care Med 2020 Mar 2 - doi: 10.1007/s00134-020-05979-7

5. Bouadma 1, Lescure FX, Lucet JC, Yazdanpanah Y, Timsit JF. Severe SARS-CoV-2 infections: practical considerations and management strategy for intensivists. Intensive Care Med 2020;46(4):579-82

6. Cronin JN, Crockett DC, Farmery AD et al. Mechanical Ventilation Redistributes Blood to Poorly Ventilated Areas in Experimental Lung Injury. Crit Care Med 2020;48(3):e200-e208.

7. Nieman GF, Gatto LA, Andrews P et al. Prevention and treatment of acute lung injury with time-controlled adaptive ventilation: physiologically informed modification of airway pressure release ventilation. Ann Intensive Care 2020;10(1):3. doi: 10.1186/s13613-019-0619-3.

8. Gattinoni L, Coppola S, Cressoni M, Busana M, Chiumello D. Covid-19 Does Not Lead to a "Typical" Acute Respiratory Distress Syndrome. Am J Resp Crit Care Med 2020 Mar 27 doi: 10.1164/rccm.202003-0817LE

9. Bendjelid K, Giraud R. Treating hypoxiemic patients with SARS-CoV-2 pneumonia. Back to applied physiology. Anaesth Crit Care Pain Med 2020 Apr 16 - https://doi.org/10.1016/j.accpm.2020.04.003

10. COVID-19 pandemic: triage for intensive-care treatment under resource scarcity. SAMW ASSM Swiss Academy of Medical Sciences, 24 Mar 2020. https://www.samw.ch/en/Ethics/Topics-A-to-Z/Intensive-caremedicine.html

11. Acute Respiratory Distress Syndrome Network, Brower RG, Matthay MA, Morris A, Schoenfeld D, Thompson BT, Wheeler A. Ventilation with lower tidal volumes as compared with traditional tidal volumes for acute lung injury and the acute respiratory distress syndrome. $N$ Engl J Med.2000;342(18):1301-8

12. Fumagalli J, Santiago RRS, Teggia Droghi M et al. Lung Recruitment in Obese Patients with Acute Respiratory Distress Syndrome. Anesthesiology 2019;130(5):791-803

13. Surviving Sepsis Campaign Rapid Guidelines on the Management of Critically Ill Adults with Coronavirus Disease 2019. ESICM Guidelines, 2020 Mar 20. https://www.esicm.org/ssc-covid19-guidelines/ 
medRxiv preprint doi: https://doi.org/10.1101/2020.05.03.20089318; this version posted May 8, 2020. The copyright holder for this preprint

(which was not certified by peer review) is the author/funder, who has granted medRxiv a license to display the preprint in perpetuity.

It is made available under a CC-BY-NC-ND 4.0 International license .

14. Kalil AC, Metersky ML, Klompas M et al. Management of Adults With Hospital-acquired and Ventilatorassociated Pneumonia: 2016 Clinical Practice Guidelines by the Infectious Diseases Society of America and the American Thoracic Society. Clin Infect Dis. 2016 Sep 1;63(5):e61-e111

15. Torres A, Niederman MS, Chastre $\mathrm{J}$ et al. International ERS/ESICM/ESCMID/ALAT guidelines for the management of hospital-acquired pneumonia and ventilator-associated pneumonia. Eur Respir J 2017;50(3) doi: $10.1183 / 13993003.00582-2017$

16. Bhatraju PK, Ghassemieh BJ, Nichols M et al. Covid-19 in Critically Ill Patients in the Seattle Region - Case Series. N Engl J Med 2020 Mar 30 - doi: 10.1056/NEJMoa2004500

17. Liao X, Wang B, Kang Y. Novel coronavirus infection during the 2019-2020 epidemic: preparing intensive care units-the experience in Sichuan Province, China. Intensive Care Med 2020;46:357-60

18. Redfern O, Smith G, Prytherch D, Meredith P, Inada-Kim M. Schmidt P. A Comparison of the Quick Sequential (Sepsis-Related) Organ Failure Assessment Score and the National Early Warning Score in Non-ICU Patients With/Without Infection. Crit Care Med 2018;46(12):1923-33

19. Wu Z, McGoogan JM. Characteristics of and Important Lessons From the Coronavirus Disease 2019 (COVID19) Outbreak in China: Summary of a Report of $72 \square 314$ Cases From the Chinese Center for Disease Control and Prevention. JAMA 2020 February 24 - doi: 10.1001/jama.2020.2648

20. Poston JT, Patel BK, Davis AM. Management of Critically Ill Adults With COVID-19. JAMA Clinical Guidelines Synopsis 2020 Mar 26 - doi: 10.1001/jama.2020.4914

21. Jianfeng Xie J, Tong Z, Guan X, Du B, Qiu HH, Slutsky AS. Critical care crisis and some recommendations during the COVID-19 epidemic in China. Intensive Care Med 2020 Mar 02 - doi.org/10.1007/s00134-02005979-7

22. Gattinoni L, Quintel M, Marini JJ. "Less is More” in mechanical ventilation. Intensive Care Med 2020;46:780-2

23. ARDS Definition Task Force, Ranieri VM, Rubenfeld GD, Thompson BT, et al. Acute respiratory distress syndrome: the Berlin Definition. JAMA 2012;307(23):2526-33

24. Guan WJ, Ni ZY, Hu Y et al. Clinical Characteristics of Coronavirus Disease 2019 in China. N Engl J Med 2020 Feb 28 - doi: 10.1056/NEJMoa2002032

25. Arentz M, Yim E, Klaff L et al. Characteristics and Outcomes of 21 Critically Ill Patients With COVID-19 in Washington State JAMA. 2020;323(16):1612-1614. doi:10.1001/jama.2020.432 
medRxiv preprint doi: https://doi.org/10.1101/2020.05.03.20089318; this version posted May 8, 2020. The copyright holder for this preprint (which was not certified by peer review) is the author/funder, who has granted medRxiv a license to display the preprint in perpetuity.

It is made available under a CC-BY-NC-ND 4.0 International license .

\section{FIGURES LEGENDS}

\section{Figure 1}

Management of the CoViD-19 patients evaluated at the CLM.

\section{Figure 2}

Patients status admitted to the ICU. At April 12 $2^{\text {th }}, 2020,10$ patients $(24.3 \%)$ died, $4(9.7 \%)$ are still receiving mechanical ventilation, 2 were transferred to another hospital and $25(60.9 \%)$ were discharged from ICU after a mean of 9 days. All data up to 7 days from extubation have been reported.

\section{Figure 3}

Overall survival rate during and after ICU admission comparison between the study cohort (class LUG; light blue, continuous line) and the data published by Bhatraju et $\mathrm{al}^{18}$ (class SEA; light green, dashed line) $(\mathrm{p}$-value = 0.028). 


\section{TABLES}

TABLE 1 Baseline characteristics

\section{DEMOGRAPHIC DATA:}

Patients admitted to ICU

Age

Male

BMI

SAPS

NEMS n.v. 41

years

$\mathrm{n}$ $\mathrm{kg} / \mathrm{m}^{2}$

Unit

2

Unit
n
years
$\mathrm{n}$
$\mathrm{kg} / \mathrm{m}^{2}$

\section{COMORBIDITIES:}

Arterial Hypertension

Ischemic cardiopathy

Diabetes

Obstructive Sleep Apnea Syndrome

COPD

\begin{tabular}{|l|l|l|}
\hline $\mathrm{n}$ & \\
\hline $\mathrm{n}$ & \\
\hline $\mathrm{n}$ & & \\
$\mathrm{n}$ & & \\
\hline $\mathrm{n}$ & & \\
\hline
\end{tabular}

$19(46 \%)$

$6(14.6 \%)$

$15(36 \cdot 5 \%)$

$6(14.6 \%)$

$4(9.7 \%)$

\section{HEMODYNAMICS:}

Mean duration of symptoms

Systolic arterial pressure

Diastolic arterial pressure

Heart Rate

Temperature

Lactate

\section{AT ADMISSION}

\section{LABORATORY:}

\begin{tabular}{|c|c|c|c|}
\hline ASAT & $\mathrm{U} / \mathrm{L}$ & $10-50$ & $66(22-197)$ \\
\hline ALAT & $\mathrm{U} / \mathrm{L}$ & $10-50$ & $48(11-123)$ \\
\hline Leucocyte & $\mathrm{G} / \mathrm{L}$ & $4 \cdot 0-10 \cdot 0$ & $9 \cdot 5(2 \cdot 8-25)$ \\
\hline Lymphocyte & $\mathrm{G} / \mathrm{L}$ & $1 \cdot 3-3 \cdot 6$ & $1 \cdot 1(0 \cdot 2-13 \cdot 2)$ \\
\hline
\end{tabular}

\section{RADIOLOGY:}

Chest-X-ray

Chest-CT-scan

$\begin{array}{ll}\text { - } & \text { NO CT-scan } \\ \text { - } & \text { Ground Glass } \\ \text { - } & \text { Ground Glass \& Consolidation }\end{array}$

$7(1-30)$

$129(80-180)$

$67(40-110)$

$88(55-160)$

$37 \cdot 0(35 \cdot 6-39)$

$1 \cdot 5(0 \cdot 5-2 \cdot 6)$
- $\quad$ Ground Glass \& Consolidation $\mathrm{n}$

n $19(46 \%)$

\begin{tabular}{l|l}
$\mathrm{n}$ & $4(9 \%)$
\end{tabular}

\begin{tabular}{l|l}
$\mathrm{n}$ & $18(42 \%)$
\end{tabular}

Demographic characteristics and blood tests at admission. Continuous measurements were presented as mean (min-max, $\pm \mathrm{SD}$ ) otherwise as median (IQR) if they are normally distributed. Categorical variables were reported as counts and percentages. 
medRxiv preprint doi: https://doi.org/10.1101/2020.05.03.20089318; this version posted May 8, 2020. The copyright holder for this preprint (which was not certified by peer review) is the author/funder, who has granted medRxiv a license to display the preprint in perpetuity.

It is made available under a CC-BY-NC-ND 4.0 International license .

TABLE 2 Lung starting situation and MV setting

\begin{tabular}{|c|c|c|c|}
\hline & Unit & n.v. & Results \\
\hline \multicolumn{4}{|l|}{ RESPIRATORY DATA: } \\
\hline $\mathrm{FiO}_{2}$ at admission & $\%$ & & $72(60-100)$ \\
\hline P/F-ratio at admission & & $>300$ & $87(54-133)$ \\
\hline Respiratory Rate & $/ \mathrm{min}$ & $<20$ & $27(12-29)$ \\
\hline $\mathrm{FiO}_{2}$ after orotracheal intubation & $\%$ & & $70(60-85)$ \\
\hline $\mathrm{P} / \mathrm{F}$-ratio after orotracheal intubation & & $>300$ & $147(101-233)$ \\
\hline \multicolumn{4}{|l|}{ VENTILATORY STRATEGY: } \\
\hline Not-intubated & $\mathrm{n}$ & & $7(17 \%)$ \\
\hline Intubated & $\mathrm{n}$ & & $34(83 \%)$ \\
\hline \multicolumn{4}{|l|}{ PEEP-strategy } \\
\hline$-\quad \mathrm{BMI}<30 \mathrm{Kg} / \mathrm{m}^{2}$ & $\mathrm{cmH}_{2} \mathrm{O}$ & & $11(10-12)-\mathrm{SD} 3 \cdot 8$ \\
\hline$-\quad$ BMI $>30 \mathrm{Kg} / \mathrm{m}^{2}$ & $\mathrm{cmH}_{2} \mathrm{O}$ & & $15(12-18)-\operatorname{SD} 3 \cdot 26$ \\
\hline
\end{tabular}

ICU respiratory data at admission, during treatment and PEEP strategy. Continuous measurements were presented as mean (min-max, $\pm \mathrm{SD}$ ) otherwise as median (IQR) if they are normally distributed. Categorical variables were reported as counts and percentages. 
medRxiv preprint doi: https://doi.org/10.1101/2020.05.03.20089318; this version posted May 8, 2020. The copyright holder for this preprint (which was not certified by peer review) is the author/funder, who has granted medRxiv a license to display the preprint in perpetuity.

It is made available under a CC-BY-NC-ND 4.0 International license .

TABLE 3 Clinical evolution

\begin{tabular}{|c|c|c|c|}
\hline & Unit & n.v. & Results \\
\hline \multicolumn{4}{|l|}{ RESPIRATORY DATA: } \\
\hline $\mathrm{P} / \mathrm{F}$ ratio at first day & & $>300$ & $100.0(67.5-153.5)$ \\
\hline $\mathrm{P} / \mathrm{F}$ ratio at second day & & $>300$ & $142.5(97.6-232.8)$ \\
\hline $\mathrm{P} / \mathrm{F}$ ratio at third day & & $>300$ & $167(113-230)$ \\
\hline Pronation cycles & $\mathrm{n}$ & & $4(1.8-5)$ \\
\hline \multicolumn{4}{|l|}{ LABORATORY DATA: } \\
\hline C-Reactive-Protein max & $\mathrm{mg} / \mathrm{L}$ & $<5$ & $235.5(171.0-318.0)$ \\
\hline Ferritin max & $\mathrm{ng} / \mathrm{mL}$ & $30-500$ & $2225(1009-3937)$ \\
\hline Lactate De-Hydrogenase max & $\mathrm{U} / \mathrm{L}$ & $135-225$ & $609(484-777)$ \\
\hline Creatinine max & umol/L & $62-106$ & $87.5(75.8-117.5)$ \\
\hline Troponin T hs max & $\mathrm{ng} / \mathrm{L}$ & & $18(10.9-95.5)$ \\
\hline Creatinine Kinase max & $\mathrm{U} / \mathrm{L}$ & 39-308 & $315(114.3-495.5)$ \\
\hline Platelets min & $\mathrm{G} / \mathrm{L}$ & $150-450$ & $223.5(170-305.3)$ \\
\hline Bilirubin total max & umol/L & $<21.0$ & $9.6(7.8-16.4)$ \\
\hline \multicolumn{4}{|c|}{ CLINICAL EVOLUTION } \\
\hline Length of hospital stay & days & & $6.5(3-10)$ \\
\hline Length of ICU stay & days & & $9(4-12.5)$ \\
\hline Length of MV & days & & $6.5(3-10)$ \\
\hline \multicolumn{4}{|c|}{ COMPLICATIONS } \\
\hline Ventilator Associated Pneumonia (VAP) & $\mathrm{n}$ & & $8(19 \%)$ \\
\hline Thromboembolism confirmed & $\mathrm{n}$ & & $26(63 \%)$ \\
\hline AKI needing CVVHDF & $\mathrm{n}$ & & $5(12.2 \%)$ \\
\hline \multicolumn{4}{|c|}{ OTHER DRUGS } \\
\hline Tocilizumab & $\mathrm{n}$ & & $20(49 \%)$ \\
\hline Lopinavir/Ritonavir & $\mathrm{n}$ & & $10(24.4 \%)$ \\
\hline Hydroxychloroquine & $\mathrm{n}$ & & $17(41.4 \%)$ \\
\hline
\end{tabular}

ICU mechanical ventilation and laboratory data. Continuous measurements were presented as mean (min-max, $\pm \mathrm{SD}$ ) otherwise as median (IQR) if they are normally distributed. Categorical variables were reported as counts and percentages. 


\section{FIGURES}

FIGURE 1

\section{CLM CoViD-19 patients (March $16^{\text {th }}-$ April $12^{\text {nd }}$ )}

Admitted to the Clinic $(n=310)$

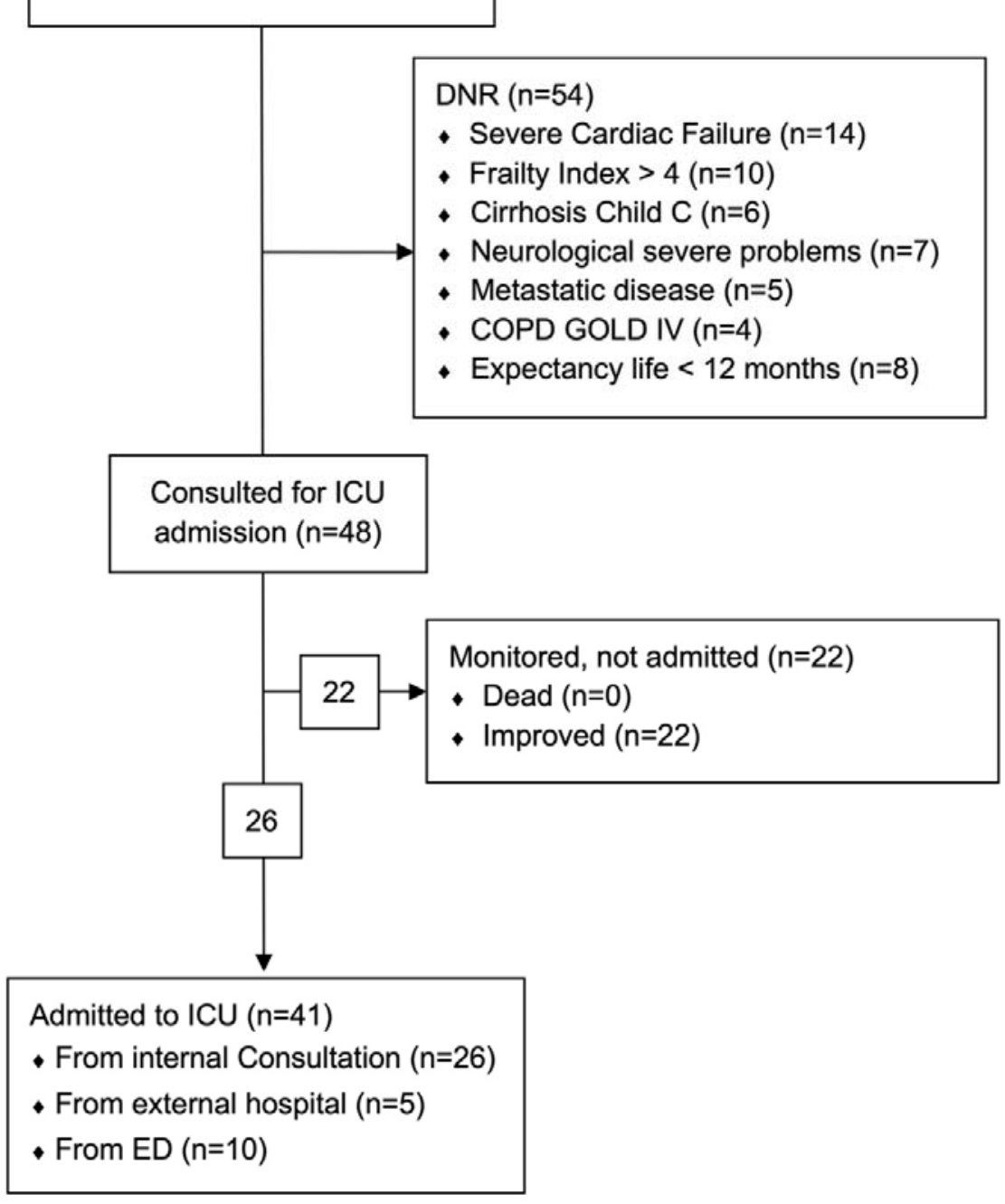


FIGURE 2

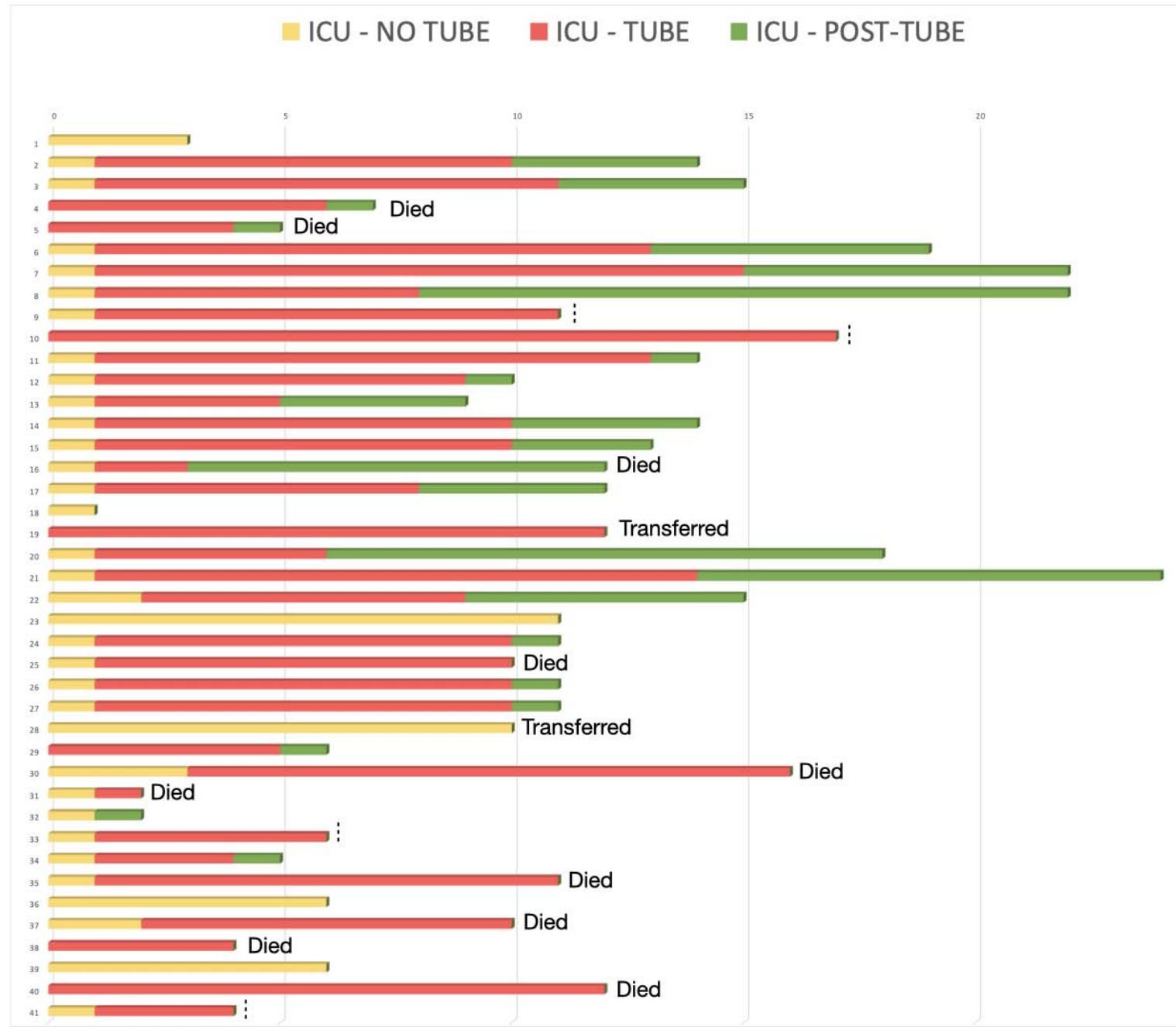


FIGURE 3

Survival - ICU Stay
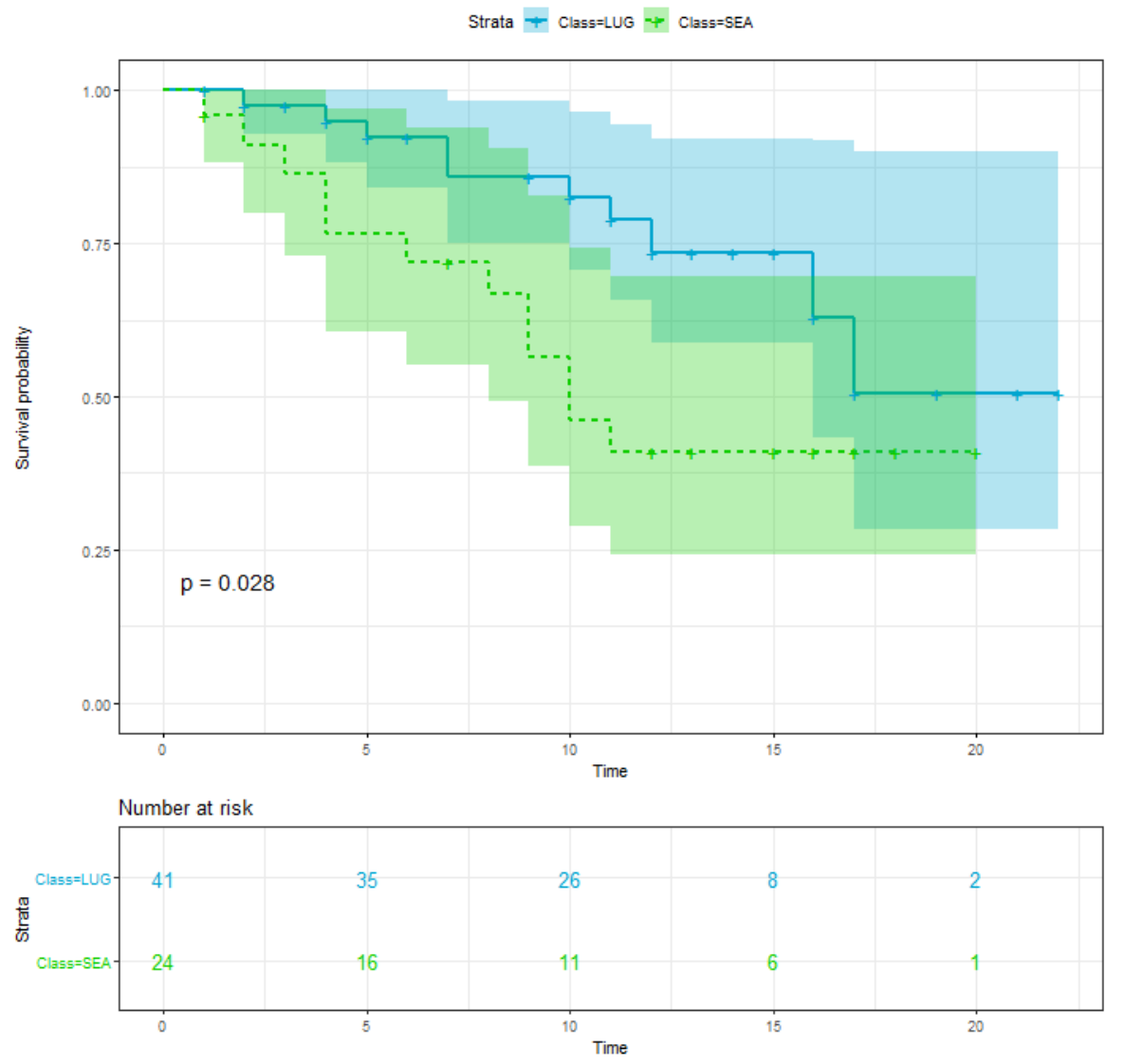

총

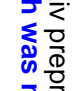

흘.

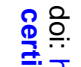

棓需

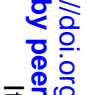

$=$

के $\overline{3}$

융

के

政节

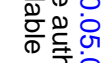

동ํㅇ

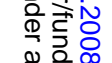

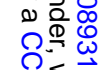

这

र을.

文需

之o일.

뭉유잉

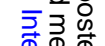

익 음음 商:

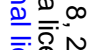

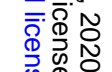

需

을

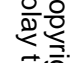

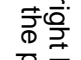

응

艼. 음

焉

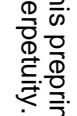

